\title{
TRAF4 wt Allele
}

National Cancer Institute

\section{Source}

National Cancer Institute. TRAF4 wt Allele. NCI Thesaurus. Code C52943.

Human TRAF4 wild type allele is located within 17q11-q12 and is approximately $6 \mathrm{~kb}$ in length. This allele, which encodes TNF receptor-associated factor 4 protein, is involved in the suppression of neurotrophin receptor-induced apoptosis. 